\title{
Screening and diagnosing postpartum depression: when and how?
}

\author{
Triagem e diagnóstico de depressão pós-parto: quando e como?
}

\author{
Gustavo Paranhos de Albuquerque Moraes, ${ }^{1}$ Laura Lorenzo, ${ }^{2}$ Gabriela Arruda Reinaux Pontes, ${ }^{1}$ \\ Maria Cristina Montenegro, ${ }^{3}$ Amaury Cantilino ${ }^{1}$
}

\begin{abstract}
Introduction: Prevalence rates of postpartum depression (PPD) vary widely, depending on the methodological parameters used in studies: differences in study populations, diagnostic methods, and postpartum time frame. There is also no consensus on the ideal time to perform screening, on whether PPD can only be diagnosed in the early postnatal period, or on how soon after a delivery depression may be related to it.

Objective: To review which instruments have been used over recent years to screen and diagnose PPD and the prevailing periods of diagnosis.

Methods: Only articles published within 5 years and related exclusively to screening and diagnosis were selected. The sample comprised 22 articles.

Results: The Edinburgh Posnatal Depression Scale (EPDS) was the most common screening tool, used in $68 \%$ of the sample (15 articles), followed by the Beck Depression Inventory (BDI-II) (27\%, 6 articles), and the Patient Health Questionnaire-9 (PHQ-9) $(18 \%, 4$ articles). Screening time frame was reported in $21 / 22$ articles: 0 to 3 months postpartum in $9(43 \%)$, up to 6 months in $4(19 \%)$, and up to 12 months or more in $8(38 \%)$. In short, 13 articles screened during the first 6 months (59\%) while only 8 (36\%) screened up to 1 year.

Conclusion: The most frequent PPD diagnosis tool was the EPDS, but other scales were also used. The most common period for diagnosis was up to 3 months postpartum. However, some researchers diagnosed PPD 12 months or more postpartum. Greater standardization of parameters for investigation of this disease is needed.
\end{abstract}

Keywords: Postpartum depression, perinatal depression, postnatal depression, screening, diagnosis.

\section{Resumo}

Introdução: A prevalência de depressão pós-parto (DPP) varia consideravelmente dependendo dos parâmetros metodológicos utilizados: diferentes populações, métodos de diagnóstico e o tempo pós-parto considerado. Também não há consenso sobre o momento ideal para a triagem, se a DPP pode ser diagnosticada apenas no período puerperal, e por quanto tempo após o parto a depressão pode ser relacionada a ele.

Objetivo: Revisar os instrumentos mais usados recentemente para rastreamento e diagnóstico de DPP e os períodos predominantes de diagnóstico.

Métodos: Foram selecionados apenas artigos relacionados exclusivamente ao rastreio e diagnóstico publicados num período de 5 anos. A amostra incluiu 22 artigos.

Resultados: A Escala de Depressão Pós-Parto de Edimburgo (EPDS) foi a ferramenta mais frequente, utilizada em $68 \%$ da amostra (15 artigos), seguida pelo Inventário de Depressão de Beck (27\%, 6 artigos) e o Patient Health Questionnaire-9 (PHQ-9) (18\%, 4 artigos). O tempo de rastreio foi definido em $21 / 22$ artigos: 0-3 meses pós-parto em 9 (43\%), < 6 meses em 4 (19\%), e $\leq 12$ meses em 8 (38\%). Treze artigos selecionaram as mulheres durante os primeiros 6 meses (59\%), enquanto apenas 8 (36\%) o fizeram até 1 ano.

Conclusão: A EPDS foi o instrumento mais utilizado para o diagnóstico de DPP, mas outras escalas também foram aplicadas. O período mais comum para o diagnóstico foi de $<3$ meses pós-parto. No entanto, alguns pesquisadores consideraram o diagnóstico de PPD em $\leq 12$ meses após o parto. Há necessidade de maior padronização de parâmetros em relação à investigação desta doença.

Descritores: Depressão pós-parto, depressão perinatal, triagem, diagnóstico.

\footnotetext{
${ }^{1}$ Universidade Federal de Pernambuco (UFPE), Recife, PE, Brazil. ${ }^{2}$ EPSIRE Centro Privado (Psiquiatría Perinatal y Psicofarmacología), Argentina. ${ }^{3}$ Universidade de Pernambuco (UPE), Recife, PE, Brazil.

Financial support: none.

Submitted Apr 29 2016, accepted for publication Aug 022016.

Conflicts of interest: Amaury Cantilino has served as a speaker for Abbott and Lundbeck. The other authors have no conflicts of interest to declare concerning the publication of this article.

Suggested citation: Moraes GP, Lorenzo L, Pontes GA, Montenegro MC, Cantilino A. Screening and diagnosing postpartum depression: when and how? Trends Psychiatry Psychother. 2017;39(1):54-61. http://dx.doi.org/10.1590/2237-6089-2016-0034
} 


\section{Introduction}

There is a long-standing association between mood swings and the postnatal period. ${ }^{1}$ Many women experience major changes in mood and/or anxiety. ${ }^{2}$ Postpartum is also considered a time of heightened vulnerability to onset of psychiatric disorders. ${ }^{3}$ Nevertheless, detection and treatment rates for perinatal depression and anxiety are alarmingly low. ${ }^{4}$

Postpartum depression (PPD) is considered the most important postpartum psychiatric disorder because prevalence rates are elevated, ranging from 10 to $20 \%$ in most studies, ${ }^{5}$ and because of the impact it has on the lives of mothers, their families, and their children. ${ }^{6}$ Additionally, women who develop postpartum depression are at greater risk of relapses during subsequent pregnancies and of developing a major depressive disorder (MDD) outside the perinatal period. ${ }^{7}$

The prevalence of PPD varies widely because of a lack of uniformity in the methodological parameters used in research, such as differences in study populations, methods of diagnosis, and the postpartum time frame considered. ${ }^{8}$ These variations can even be observed within the same country. For example, in India rates ranging from $6^{9}$ to $45 \%^{10}$ and in Brazil rates from 12 to $37 \%^{11}$ have been observed. The reasons for this are not limited to sociocultural characteristics of study populations, but also include differences in the methodologies used in the studies.

Screening tools for health care settings are an important component of recommended depression treatment guidelines and of provision of mental health services. ${ }^{12}$ In their Committee Opinion on screening for perinatal depression, the American College of Obstetricians and Gynecologists $^{13}$ recommend seven screening tests that have been validated for use during pregnancy and the postpartum period - the Edinburgh Postnatal Depression Scale (EPDS), the Postpartum Depression Screening Scale (PDSS), the Patient Health Questionnaire-9 (PHQ-9), the Beck Depression Inventory (BDI), the Beck Depression Inventory II (BDI-II), the Center for Epidemiologic Studies Depression Scale (CES-D), and the Zung SelfRating Depression Scale (Zung SDS) - but they do not provide specific guidance on which are more appropriate in particular settings or on the best time frame for detection of PPD.

The instruments most frequently used to diagnose PPD are the same as those administered to detect MDD: the Structured clinical interview for DSM-IV-TR Axis I Disorders ${ }^{14}$ and the Mini-International Neuropsychiatric Interview (MINI). ${ }^{15}$

There is also no consensus on the ideal time to conduct screening, whether it is only possible to diagnose PPD during the puerperal period, or on how soon after a delivery depression may be related to it. ${ }^{3}$ Timely recognition of maternal distress, both physical and psychological, during the course of pregnancy and in the postpartum period, are important concerns for health care professionals. ${ }^{16}$

It is necessary to define the most appropriate time and method for detecting PPD, so interventions to reduce this condition's impact on maternal and child health can be developed. This study aims to review which instruments have been used over recent years for screening and diagnosis of PPD, and what are the prevailing periods of time during which this diagnosis has been made.

\section{Methods}

This review is part of a broader study based on a protocol that conforms to the Preferred Reporting Items for Systematic Reviews and Meta-analyses (PRISMA) model. The methodological protocol was constructed by one of the authors as part of his master's dissertation and published in the annals of the Universidade Federal de Pernambuco. ${ }^{17,18}$ For this study, the PRISMA model was not followed rigorously.

Searches were run on three databases, MEDLINE, SciELO, and LILACS, using the clinical terms postpartum depression, postnatal depression, perinatal depression and puerperal depression in publication titles, plus one of the diagnostic terms screening, diagnosis, diagnostic, evaluation, interview, questionnaire, scale, score, cutoff, or time, in either title or abstract.

Inclusion criteria were original articles published in English during the previous 5 years (up to June 30, 2014) describing studies of female humans and containing at least one of the terms, referring to instruments used in screening, diagnosis, evaluation, or time for assessment of PPD, in the title or abstract. Articles were excluded if they were not original, were review papers (except for meta-analyses), or were case reports. We only included papers in which the main objectives were related to diagnosis and/or screening.

Two reviewers assessed the results of the search, screening titles and abstracts to select articles according to the inclusion criteria. The degree of agreement between them was evaluated using the kappa statistic. Disagreements were resolved by consensus. Only one of the authors reviewed the full-text of the articles selected.

\section{Results}

The initial search using clinical terms identified 2,057 papers. Of these, 722 had one or more of the 
diagnostic terms in the title or abstract. After application of exclusion criteria, 372 items remained. After removal of 16 duplicates, a total of 356 abstracts were read by two reviewers and those that did not meet the inclusion criteria for the study were excluded. The result of the Kappa test used to assess the level of agreement between reviewers was 0.72 ( $p<0.001 ; 95 \%$ confidence interval [95\%CI] 0.62-0.82). After disagreements had been discussed, a total of 181 abstracts were included. Of these, the full texts of 5 were not retrieved and 22 were excluded after reading because they did not meet inclusion criteria. The total sample comprised 154 articles.

To fulfill the primary objective, each article was classified according to 6 categories: risk factors and etiology; prevalence; screening and diagnostic instrument validation; prevention and treatment; and consequences. Only items related to screening and diagnosis were used to achieve the objectives defined for this paper. The resulting sample comprised 22 articles (12\% of a total sample of 154 papers that was compiled for the original Universidade Federal de Pernambuco publication) (Table 1).

Table 1 - Studies and screening tools

\begin{tabular}{|c|c|c|c|c|c|c|c|}
\hline \multirow{2}{*}{$\begin{array}{l}\text { Author and } \\
\text { year }\end{array}$} & \multirow[b]{2}{*}{ Country } & \multirow{2}{*}{$\begin{array}{l}\text { Sample } \\
\text { size }\end{array}$} & \multirow{2}{*}{$\begin{array}{l}\text { Screening } \\
\text { tool }\end{array}$} & \multirow{2}{*}{$\begin{array}{l}\text { EPDS } \\
\text { cutoff } \\
\text { score }\end{array}$} & \multicolumn{2}{|c|}{$\begin{array}{c}\text { Last time for screening } \\
\text { after delivery }\end{array}$} & \multirow[b]{2}{*}{ Comments } \\
\hline & & & & & Weeks & Months & \\
\hline $\begin{array}{l}\text { Horowitz et } \\
\text { al. }{ }^{19}\end{array}$ & USA & 5,169 & EPDS & $>10$ & 04 & 01 & $\begin{array}{l}\text { PPD was defined as beginning by } 4 \\
\text { weeks. Of this group, } 674(13 \%) \\
\text { women had EPDS scores }>10 .\end{array}$ \\
\hline Miller et al. ${ }^{20}$ & USA & 5,439 & EPDS & $>10$ & 48 & 12 & $\begin{array}{l}\text { Among women eligible for screening, } \\
62.5 \% \text { completed screening and } \\
17.1 \% \text { of the women screened were } \\
\text { identified as having depressive } \\
\text { symptoms (EPDS }>10 \text { ). }\end{array}$ \\
\hline $\begin{array}{l}\text { Shelton \& } \\
\text { Herrick }^{21}\end{array}$ & UK & 394 & EPDS & $>10$ & 48 & 12 & $\begin{array}{l}\text { There was reasonable correlation } \\
\text { between the scoring methods over } \\
\text { time, except at } 4 \text { months after } \\
\text { delivery when the EPDS showed } \\
\text { an upward spike and the GHQ-12 } \\
\text { showed a plateau. This difference } \\
\text { was statistically significant ( } \mathrm{p}< \\
0.000,95 \% \text { CI }-3.330-0.550, \mathrm{n}=27 \text { ) } \\
\text { and would result in mothers being } \\
\text { diagnosed using the EPDS but not } \\
\text { the GHQ-12. The prevalence of PPD } \\
\text { was } 24.4 \% \text { using the EPDS. }\end{array}$ \\
\hline Yawn et al. ${ }^{22}$ & USA & 481 & $\begin{array}{l}\text { EPDS } \\
\text { PHQ-9 }\end{array}$ & $\geq 10$ & 12 & 03 & $\begin{array}{l}\text { There was concordance between } \\
\text { the EPDS and PHQ-9 in } 399 \text { women } \\
(83 \%): 326(67.8 \%) \text { had a "normal" } \\
\text { score on both, and } 73(15.2 \%) \text { had } \\
\text { elevated scores for both. Discordant } \\
\text { scores in the remaining } 82 \text { women } \\
\text { included } 17 \text { with elevated PHQ-9 } \\
\text { scores, but normal EPDS scores, and } \\
65 \text { with elevated EPDS scores and } \\
\text { PHQ-9 scores < } 10 \text {. }\end{array}$ \\
\hline $\begin{array}{l}\text { O'Mahen et } \\
\text { al. }{ }^{23}\end{array}$ & USA & 1,285 & $\begin{array}{l}\text { EPDS } \\
\text { BDI-II } \\
\text { IPQ }\end{array}$ & $\geq 10$ & 06 & 1.5 & $\begin{array}{l}\text { In this group, } 15.9 \%(n=204) \\
\text { scored } \geq 10 \text { on the EPDS. }\end{array}$ \\
\hline Phillips et al. ${ }^{24}$ & Australia & 309 & $\begin{array}{l}\text { EPDS } \\
\text { BDI-II } \\
\text { BAI }\end{array}$ & $\geq 13$ & 48 & 12 & $\begin{array}{l}\text { For the total scale (EPDS), } 30 \text { of the } \\
42 \text { women diagnosed with a DSM- } \\
\text { IV major depressive episode were } \\
\text { correctly identified using a cutoff } \\
\text { score of } 13 \text { or more (sensitivity } \\
71 \% \text { ), and there were } 24 \text { false } \\
\text { positives (misclassification rate } \\
22 \% \text { ). }\end{array}$ \\
\hline $\begin{array}{l}\text { Goodman \& } \\
\text { Tyer-Viola }^{4}\end{array}$ & USA & 491 & EPDS & $\geq 10$ & 06 & 1.5 & $\begin{array}{l}\text { Twenty-three percent of participants } \\
\text { screened positive for an anxiety } \\
\text { disorder or high levels of depressive } \\
\text { symptoms or both prenatally, and } \\
17 \% \text { screened positive at } 6 \text { weeks } \\
\text { postpartum. }\end{array}$ \\
\hline
\end{tabular}




\begin{tabular}{|c|c|c|c|c|c|c|c|}
\hline Hayes et al. ${ }^{7}$ & $\begin{array}{c}\text { USA } \\
\text { (Hawaii) }\end{array}$ & 7,154 & $\begin{array}{l}\text { SRPDS } \\
\text { PHQ-2 }\end{array}$ & - & - & - & $\begin{array}{l}\text { Of all women in Hawaii with a } \\
\text { recent live birth, } 14.5 \% \text { had } \\
\text { SRPDS. This study assessed } \\
\text { estimates of postpartum depression } \\
\text { in the Hawaiian community and } \\
\text { demonstrated that almost half } \\
\text { ( } 45.6 \% \text { ) of women who recently } \\
\text { gave birth to a live infant reported } \\
\text { symptoms that might warrant } \\
\text { further evaluation for postpartum } \\
\text { depression. }\end{array}$ \\
\hline $\begin{array}{l}\text { Zubaran et } \\
\text { al. }{ }^{16}\end{array}$ & Brazil & 101 & $\begin{array}{c}\text { SCID } \\
\text { GHQ-12 } \\
\text { PHQ } \\
\text { PDSS } \\
\text { EPDS }\end{array}$ & $\geq 13$ & 12 & 03 & $\begin{array}{l}\text { In effect, the GHQ and the EPDS } \\
\text { were considered valuable screening } \\
\text { tools for detecting depression during } \\
\text { the postpartum period as well as } \\
\text { anxiety and adjustment disorders } \\
\text { when conjointly tested. }\end{array}$ \\
\hline Lau et al. ${ }^{25}$ & China & 610 & EPDS & $\begin{array}{c}>9 \\
>14\end{array}$ & 06 & 1.5 & $\begin{array}{l}\text { The percentage of women with } \\
\text { an EPDS score }>9 \text { was } 36.5 \% \text { ( } n \\
=796) \text { in the second trimester, } \\
\text { decreasing to } 32.0 \%(n=502) \text { in } \\
\text { the third trimester and } 31.6 \% \text { ( } n= \\
193 \text { ) at } 6 \text { weeks postpartum. The } \\
\text { rates were } 9.9 \%, 7.8 \%, \text { and } 8.7 \% \\
\text { for an EPDS score of }>14 \text { in the } \\
\text { second and third trimesters and at } \\
6 \text { weeks postpartum, respectively. } \\
\text { Women with a second trimester } \\
\text { EPDS score > } 14 \text { were } 11.78 \text { times } \\
\text { more likely in the third trimester and } \\
7.15 \text { times more likely at } 6 \text { weeks } \\
\text { postpartum to exhibit perinatal } \\
\text { depressive symptomology. }\end{array}$ \\
\hline Flynn et al. ${ }^{26}$ & USA & 185 & $\begin{array}{l}\text { EPDS } \\
\text { PHQ-9 }\end{array}$ & $\geq 13$ & 52 & 13 & $\begin{array}{l}\text { This study found few significant } \\
\text { differences in the performance of } \\
\text { the PHQ-9 and EPDS for detecting } \\
\text { clinician-diagnosed major depressive } \\
\text { disorder in a psychiatric outpatient } \\
\text { sample of pregnant and postpartum } \\
\text { women. }\end{array}$ \\
\hline $\begin{array}{l}\text { Gjerdingen et } \\
\text { al. }{ }^{27}\end{array}$ & USA & 506 & $\begin{array}{l}\text { SCID } \\
\text { PHQ-9 }\end{array}$ & - & 36 & 09 & $\begin{array}{l}\text { Forty-five women }(8.9 \%) \text { had a } \\
\text { positive SCID interview and } 112 \\
(22.1 \%) \text { had a positive PHQ-9 at } 0 \\
\text { to } 9 \text { months postpartum. }\end{array}$ \\
\hline $\begin{array}{l}\text { Reichenheim } \\
\text { et al. }{ }^{28}\end{array}$ & Brazil & 811 & EPDS & $\geq 12$ & 20 & 05 & $\begin{array}{l}\text { The mean EPDS score was } 7.8 \\
(95 \% \text { CI } 7.4-8.2) \text { and } 24.3 \%(95 \% \mathrm{CI} \\
21.3-27.2) \text { of the women scored at } \\
\text { or above the cutoff point of } 12 \text {. }\end{array}$ \\
\hline $\begin{array}{l}\text { Christensen } \\
\text { et al. }{ }^{29}\end{array}$ & USA & 215 & BDI-II & - & 48 & 12 & $\begin{array}{l}\text { Women who reported unintended } \\
\text { pregnancies were over five times } \\
\text { more likely to follow the "Postpartum } \\
\text { High" depression pattern (RR = } \\
5.22 \text {, p }<0.05 \text { ), compared to women } \\
\text { with an intentional pregnancy. }\end{array}$ \\
\hline Tandon et al. ${ }^{30}$ & USA & 95 & $\begin{array}{l}\text { EPDS } \\
\text { CES-D } \\
\text { BDI-II }\end{array}$ & $\geq 13$ & 24 & 06 & $\begin{array}{l}\text { Over a quarter of women ( } 28.4 \%) \\
\text { were experiencing major depression. } \\
\text { Each screening tool was highly } \\
\text { accurate in detecting major } \\
\text { depression and major or minor } \\
\text { depression among prenatal and } \\
\text { postpartum women. }\end{array}$ \\
\hline O'Hara et al. ${ }^{31}$ & USA & 1,077 & $\begin{array}{l}\text { BDI } \\
\text { IDAS-GD } \\
\text { EPDS }\end{array}$ & $>12$ & 56 & 14 & $\begin{array}{l}\text { Rates of moderate to severe } \\
\text { depression, based on the EPDS, } \\
\text { BDI, and IDAS-GD ranged from } 11 \\
\text { to } 16 \% \text {. }\end{array}$ \\
\hline Mann et al. ${ }^{32}$ & UK & 152 & $\begin{array}{l}\text { Two brief } \\
\text { case-finding } \\
\text { questions }\end{array}$ & - & 13 & 3.25 & $\begin{array}{l}\text { The proportion of participants who } \\
\text { met the criteria for depression } \\
\text { (minor and major) during the } \\
\text { postnatal phase was } 19.2 \% \text { ( } 95 \% \mathrm{CI} \\
12-28.9 \text { ). The brevity of the case- } \\
\text { finding questions has substantial } \\
\text { appeal for identification of perinatal } \\
\text { depression in frontline health care } \\
\text { services. }\end{array}$ \\
\hline
\end{tabular}




\begin{tabular}{|c|c|c|c|c|c|c|c|}
\hline Kim et al. ${ }^{33}$ & USA & 324 & EPDS & $\geq 10$ & 1.43 & 0.33 & $\begin{array}{l}\text { Postpartum depression symptoms } \\
\text { were present in } 17 \%(\mathrm{n}=55) \text { (EPDS } \\
\geq 10)\end{array}$ \\
\hline Maia et al. ${ }^{34}$ & Portugal & 386 & BDI-II & - & 12 & 03 & $\begin{array}{l}\text { Observed postpartum period } \\
\text { prevalence rates (from birth to the } \\
\text { 3rd month postpartum) were } 11.7 \% \\
(n=45)(\text { major depression/DSM-IV) } \\
\text { and } 16.6 \%(n=64) \text { (depressive } \\
\text { disorder/ICD-10). }\end{array}$ \\
\hline $\begin{array}{l}\text { Čuržik \& } \\
\text { Begić }^{35}\end{array}$ & Croatia & 46 & BDI-II & - & 08 & 02 & $\begin{array}{l}\text { Depression symptoms measured } \\
\text { two months postpartum were } \\
\text { significantly lower than when } \\
\text { measured during the late stage of } \\
\text { pregnancy ( } t=8.377, \mathrm{df}=49, \mathrm{p} \\
<0.01) \text {. During the late stage of } \\
\text { pregnancy, BDI-II items with highest } \\
\text { mean scores were those measuring } \\
\text { somatic symptoms of depression. } \\
\text { Depression measured during the } \\
\text { late stage of pregnancy correlated } \\
\text { significantly with maximum labor } \\
\text { pain expectancies ( } r=0.41, \mathrm{p} \\
<0.01 \text { ). Use of standardized } \\
\text { questionnaires with a high rate } \\
\text { of somatic items such as BDI-II } \\
\text { may not be the best solution when } \\
\text { screening for mood disorders in } \\
\text { pregnant women. }\end{array}$ \\
\hline Apter et al. ${ }^{36}$ & France & 109 & MADRS & - & 12 & 03 & $\begin{array}{l}\text { Of } 109 \text { women in the sample, } 39 \\
\text { had a MADRS score of } 15 \text { or more; } \\
\text { i.e., } 36 \% \text { met the criteria for a } \\
\text { depressive episode. Five had a score } \\
\text { of } 30 \text { or more, indicating a severe } \\
\text { depressive condition. }\end{array}$ \\
\hline Baines et al. ${ }^{37}$ & UK & 43 & $\begin{array}{c}\text { EPDS } \\
\text { PHQ-9 }\end{array}$ & $\geq 10$ & 16 & 04 & $\begin{array}{l}\text { The EPDS median was } 17 \\
\text { (range1/410-27) confirming that } \\
\text { participants were experiencing } \\
\text { probable depression, with } 39 \\
\text { participants scoring } 12 \text { or above, } 2 \\
\text { scoring } 11 \text { and } 4 \text { scoring } 10 \text {. }\end{array}$ \\
\hline
\end{tabular}

95\%CI $=95 \%$ confidence interval; BAI = Beck Anxiety Inventory; BDI-II = Beck Depression Inventory II; CES-D = Center for Epidemiologic Studies Depression Scale; df = degrees of freedom; DSM-IV = Diagnostic and Statistical Manual of Mental Disorders, 4th edition; EDPS = Edinburgh Postnatal Depression Scale; GHQ-12 = General Health Questionnaire-12; IDAS-GD = Inventory of Depression and Anxiety Symptoms; ICD-10 = International Classification of Diseases, 10 th revision; IPQ = Illness Perception Questionnaire; MADRS = MontgomeryÅsberg Depression Rating Scale; PDSS = Postpartum Depression Screening Scale; PHQ = Patient Health Questionnaire; PHQ-9 = Patient Health Questionnaire-9; PPD = prevalence of postpartum depression; RR = relative risk; SCID-I = Structured Clinical Interview for DSM-IV diagnosis; SRPDS $=$ Self-reported Postpartum Depressive Symptoms.

The EPDS was the most frequent screening tool, used in $68 \%$ of the sample ( 15 articles), followed by the BDIII $(27 \%, 6$ articles), the PHQ-9 (18\%, 4 articles), and the CES-D ( $9 \%, 1$ article). The PDSS was only used in one study.16 The SCID diagnostic questionnaire was used in 6 studies (27\%). Some articles used more than one instrument. Other questionnaires used were the General Health Questionnare-12 (GHQ-12), the Illness Perception Questionnaire (IPQ) and the MontgomeryÅsberg Depression Rating Scale (MADRS), none of which are specifically for postpartum depression. When using the EPDS, the mean cutoff score was 11.5 (range 10 to 14), while the most frequently used score was 10.

With regard to the time frame for detection of postpartum depression, 21 of the 22 studies defined the screening time frame. Nine studies used from 0 to
3 months postpartum (43\%), four from 4 to 6 months (19\%), and eight from 7 to 12 months or more (38\%). In other terms, 13 articles screened during the first 6 months (59\%) while only $8(36 \%)$ conducted screening between 7 months and 1 year. More specifically, in the first of these groups, only 5 out of 13 papers made diagnoses during the first 6 weeks postpartum, considered the upper time limit according to diagnostic manuals.

\section{Discussion}

This study shows the importance of the EPDS as the most common instrument for PPD screening. In the early $90 \mathrm{~s}$, the BDI was the screening tool most commonly 
used by researchers to detect PPD. ${ }^{38}$ An important limitation of that instrument, and of all others created for screening depression in general, is the inclusion of several somatic symptoms. At this stage, it becomes difficult to distinguish between normal physiological reactions and symptoms of postpartum depression. ${ }^{39}$ Because of this, specific instruments to detect PPD have been developed, like the EPDS and the PDSS. The EPDS was developed specifically to avoid over-identification of PPD based on "physical" symptoms such as fatigue, weight and appetite changes, and problems with sleeping that can be suggestive of depression but are a normal part of postpartum recovery. ${ }^{22}$ These scales focus on the cognitive and affective features of depression. ${ }^{25}$

Of all the tools specifically developed to detect PPD, the EPDS40 is the most often used in research. It was developed to help health professionals in selecting community samples of mothers with postpartum depressive symptoms. ${ }^{41}$ It is a self-report instrument containing 10 questions about symptoms of depression present in the preceding 7 days. Each question is rated on a scale of 0 to 3, and total scores can range from 0 to 30.40 The cutoffs selected by the authors of the scale for women after childbirth are 9/10 for possible depression or a minor depressive disorder, and 12/13 for probable depression or MDD. For studies in pregnant women a cutoff point of $14 / 15$ for probable depression is used. ${ }^{42}$ The EPDS has been used in more than 20 countries for identification of PPD symptoms with significant levels of sensitivity (86\%) and specificity (78\%) and offers the advantage of being free of charge. ${ }^{43}$ It is easy to apply and has good acceptability. It has been recommended for detection of depression, not only after birth but also during pregnancy. ${ }^{44}$ Many researchers question using the scale alone for diagnosis of PPD, because even though it is considered a good tool for screening for PPD, it has not been validated as a diagnostic tool. ${ }^{45}$ It is important to bear in mind that the gold standard for diagnosis remains a diagnostic interview performed by a trained professional. ${ }^{19}$

Since it is the most used tool, this review examined the EPDS cutoff scores used in the studies. The cutoff score depends on several factors, including the purpose of use. If the goal is to identify as many cases of possible, lower values should be considered, thereby increasing the instrument's sensitivity. In contrast, if the aim is to find cases close to full diagnosis, the specificity of the instrument must be increased by raising the cutoff score. ${ }^{42}$ The EPDS is considered a sensitive (96\%) screening tool for PPD, but is only moderately specific $(82 \%)$ (positive predictive value: $23 \%$ ) when a score of $\geq 10$ is used, to provide an indication that further assessment is warranted. 22,46 The low cutoff values observed in this review lead to the assumption that the studies included were intended to detect the greatest number of possible cases of postpartum depression.

Another objective of this study was to explore the time frame most frequently used for detection of PPD. In this regard, we observed that almost half of the studies included explored the range of from birth to 3 months postpartum, followed by more than one third of the sample focusing on the range of 7 to 12 months. These findings show that the period of risk for postpartum depression extends beyond the range of the first 4 to 6 weeks that is proposed by the current diagnostic manuals. The findings also indicate that the estimated time for postpartum depression goes well beyond the early weeks from birth up to one year after delivery. This is of great importance to developing screening strategies and specific therapeutic approaches for this type of depression.

A meta-analysis conducted by O'Hara and Swain showed a prevalence rate of postpartum depression of $13 \%$, based on studies that evaluated symptoms from at least 2 weeks after delivery up to 3 months beyond this period. ${ }^{47}$ Gaynes et al. reported that the pointprevalence of major depression alone ranged from 1.0 to $5.9 \%$ at different times during the first year after delivery. ${ }^{48}$ In turn, the results for period prevalence showed that $19.2 \%$ (95\%CI $10.7-31.9)$ of new mothers may have major/minor depression in the first 3-months postpartum, with as many as $7.1 \%$ (95\%CI $4.1-11.7$ ) having major depression. Some other studies have reported that prevalence is higher in the 6 months after birth. ${ }^{49,50}$

The fourth edition of DSM introduced the "postpartum onset" specifier for women who met the diagnostic criteria for MDD, beginning at up to 4 weeks after birth, and this was not changed in the review of the fourth edition, the DSM-IV-TR. ${ }^{51}$ In the fifth edition, the specifier was changed to "peripartum onset," which could be applied to the current or most recent episode of major depression if onset of mood symptoms occurs during pregnancy or in the 4 weeks following delivery. The diagnosis therefore now includes cases of major depression that have already begun during pregnancy, but the criteria do not extend the postpartum period beyond 4 weeks after birth.

Although the change in the fifth edition of the Diagnostic and Statistical Manual of Mental Disorders(DSM-5) ${ }^{52}$ encompassing cases of depression beginning in the prenatal period is itself considered a breakthrough, researchers and scholars working on PPD have questioned the short postpartum time covered in the diagnostic manuals, which is very different to what has already become well established in professional 
practice and in scientific research on the subject. ${ }^{53} \mathrm{~A}$ large group of researchers in the field support extension of the length of time covered in the next revision of the DSM- $5,{ }^{54}$ so that the diagnostic manuals come to reflect what is already being seen in research and clinical practice.

This aspect is of substantial importance since women and health care systems are being encouraged to participate in programs involving depression screening. There is direct and indirect evidence suggesting that screening pregnant and postpartum women for depression may reduce depressive symptoms in women with depression and reduce the prevalence of depression in a given population. ${ }^{55}$

This review has some limitations. Regarding the search strategy, for example, the time restriction of the last 5 years limits the number of items identified, but on the other hand it allows recent trends in research on this topic to be observed.

Another potential limitation is the decision to only include original articles, resulting in fewer studies on the subject, but this is justified by the need to use a class of article that is considered the gold standard in terms of scientific methodology.

Another limiting factor refers to the choice of only one language, English. This is because it is the most widely used for scientific communication in different cultures and is the language of scientific publications with the highest impact.

Concerns about the scientific quality of publications make it necessary to use only internationally recognized databases, so this study used MEDLINE (via PubMed), SCIELO, and LILACS. The second and third of these could have introduced another search bias, since they are more connected to Latin America.

\section{Conclusions}

Despite a significant degree of variation between the studies, the predominant screening tool used was the EPDS. In relation to time of screening, the results indicate that detection of PPD extends far beyond what is currently recommended in the DSM-5, with depressive episodes diagnosed from birth to 1 year after delivery.

This study attempts to highlight the need for greater standardization of parameters in relation to investigation of this disease. Postpartum depression merits special attention to prevention, diagnosis, and treatment. Therefore, achieving consensus on the duration of the period during which efforts should be made to detect the disorder is very important when new guidelines and strategies for these purposes are being considered and should improve the quality of public health care policies for women.

These results should contribute to progress towards better understanding of this serious disease and therefore to improving care for women during this unique period of their lives, and preventing adverse consequences for mothers and children.

\section{References}

1. Miller LJ. Postpartum depression. JAMA. 2002;287:762-5.

2. Pereira PK, Lovisi GM. Prevalência da depressão gestacional e fatores associados. Rev Psiquiatr Clin. 2008;35:144-53.

3. Cantilino A. Por um consenso conceitual e metodológico nas pesquisas em depressão pós-parto. J Bras Psiquiatr. 2010;59:257.

4. Goodman JH, Tyer-Viola L. Detection, treatment, and referral of perinatal depression and anxiety by obstetrical providers. J Womens Health (Larchmt). 2010;19:477-90.

5. Moraes IG, Pinheiro RT, Silva RA, Horta BL, Sousa PL, Faria AD. [Prevalence of postpartum depression and associated factors]. Rev Saude Publica. 2006;40:65-70.

6. Robinson GE, Stewart DE. Psychological aspects of women's health care. In: Stotland NL, Stewart DE, editors. Postpartum disorders. 2nd ed. Washington: American Psychiatry Press; 2001. p. 117-39.

7. Hayes DK, Ta VM, Hurwitz EL, Mitchell-Box KM, Fuddy LJ. Disparities in self-reported postpartum depression among Asian, Hawaiian, and Pacific Islander Women in Hawaii: Pregnancy Risk Assessment Monitoring System (PRAMS), 2004-2007. Matern Child Health J. 2010;14:765-73.

8. Lobato G, Moraes CL, Reichenheim ME. Magnitude da depressão pós-parto no Brasil: uma revisão sistemática. Rev Bras Saude Mater Infant. 2011;11:369-79.

9. Dubey C, Gupta N, Bhasin S, Muthal RA, Arora R. Prevalence and associated risk factors for postpartum depression in women attending a tertiary hospital, Delhi, India. Int J Soc Psychiatry. 2012;58:577-80.

10. Divakar H, Girish N, Gururaj G. Use of Edinborough Postnatal Depression Scale (EPDS) in a private obstetrics setting. J Obstet Gynecol India. 2008;58:41-4.

11. Lobato G, Moraes CL, Dias AS, Reichenheim ME. Postpartum depression according to time frames and sub-groups: a survey in primary health care settings in Rio de Janeiro, Brazil. Arch Womens Ment Health. 2011;14:187-93.

12. Flynn HA, Sexton M, Ratliff S, Porter K, Zivin K. Comparative performance of the Edinburgh Postnatal Depression Scale and the Patient Health Questionnaire-9 in pregnant and postpartum women seeking psychiatric services. Psychiatry Res. 2011;187:130-4.

13. Committee on Obstetric Practice. The American College of Obstetricians and Gynecologists Committee Opinion no. 630. Screening for perinatal depression. Obstet Gynecol. 2015; 125:1268-71.

14. First MB, Spitzer RL, Gibbon M, Williams JB. Structured Clinical Interview for DSM-IV-TR Axis I Disorders, Research Version, NonPatient Edition (SCID-I/NP). New York: Biometrics Research; 2002.

15. Sheehan DV, Lecrubier $Y$, Sheehan KH, Amorim $P$, Janavs J, Weiller $\mathrm{E}_{\text {, }}$ et al. The Mini-International Neuropsychiatric Interview (M.I.N.I.): the development and validation of a structured diagnostic psychiatric interview for DSM-IV and ICD-10. J Clin Psychiatry. 1998;59:22-33.

16. Zubaran C, Foresti K, Schumacher MV, Amoretti AL, Thorell MR, Müller LC. The correlation between postpartum depression and health status. Matern Child Health J. 2010;14:751-7.

17. Moher D, Liberati A, Tetzlaff J, Altman DG; PRISMA Group. Preferred reporting items for systematic reviews and meta-analyses: the PRISMA statement. BMJ. 2009;339:b2535.

18. Moraes GP. Revisão sistemática dos parâmetros metodológicos utilizados nos artigos científicos sobre os instrumentos de pesquisa e o tempo relacionados a triagem, diagnóstico e avaliação da depressão pós-parto (dissertation). Recife: Universidade Federal de Pernambuco; 2015.

19. Horowitz JA, Murphy CA, Gregory KE, Wojcik J. Best practices: community-based postpartum depression screening: results from 
the CARE study. Psychiatr Serv. 2009;60:1432-4.

20. Miller L, Shade M, Vasireddy V. Beyond screening: assessment of perinatal depression in a perinatal care setting. Arch Womens Ment Health. 2009;12:329-34.

21. Shelton NJ, Herrick KG. Comparison of scoring methods and thresholds of the General Health Questionnaire-12 with the Edinburgh Postnatal Depression Scale in English women. Public Health. 2009;123:789-93.

22. Yawn BP, Pace W, Wollan PC, Bertram S, Kurland M, Graham D, et al. Concordance of Edinburgh Postnatal Depression Scale (EPDS) and Patient Health Questionnaire (PHQ-9) to assess increased risk of depression among postpartum women. J Am Board Fam Med. 2009;22:483-91.

23. O'Mahen HA, Flynn HA, Chermack S, Marcus S. Illness perceptions associated with perinatal depression treatment use. Arch Womens Ment Health. 2009; 12:447-50.

24. Phillips J, Charles M, Sharpe L, Matthey S. Validation of the subscales of the Edinburgh Postnatal Depression Scale in a sample of women with unsettled infants. J Affect Disord. 2009;118:10112.

25. Lau Y, Wong DF, Chan KS. The utility of screening for perinatal depression in the second trimester among Chinese: a threewave prospective longitudinal study. Arch Womens Ment Health. 2010;13:153-64.

26. Flynn HA, Sexton M, Ratliff S, Porter K, Zivin K. Comparative performance of the Edinburgh Postnatal Depression Scale and the Patient Health Questionnaire-9 in pregnant and postpartum women seeking psychiatric services. Psychiatry Res. 2011;187:130-4.

27. Gjerdingen D, McGovern P, Center B. Problems with a diagnostic depression interview in a postpartum depression trial. J Am Board Fam Med. 2011;24:187-93.

28. Reichenheim ME, Moraes CL, Oliveira AS, Lobato G. Revisiting the dimensional structure of the Edinburgh Postnatal Depression Scale (EPDS): empirical evidence for a general factor. BMC Med Res Methodol. 2011;11:93.

29. Christensen AL, Stuart EA, Perry DF, Le HN. Unintended pregnancy and perinatal depression trajectories in low-income, high-risk Hispanic immigrants. Prev Sci. 2011;12:289-99.

30. Tandon SD, Cluxton-Keller F, Leis J, Le HN, Perry DF. A comparison of three screening tools to identify perinatal depression among lowincome African American women. J Affect Disord. 2012;136:15562.

31. O'Hara MW, Stuart S, Watson D, Dietz PM, Farr SL, D'Angelo D. Brief scales to detect postpartum depression and anxiety symptoms. J Womens Health (Larchmt). 2012;21:1237-43.

32. Mann R, Adamson J, Gilbody SM. Diagnostic accuracy of casefinding questions to identify perinatal depression. CMAJ. 2012;184:E424-30.

33. Kim HG, Geppert J, Quan T, Bracha Y, Lupo V, Cutts DB. Screening for postpartum depression among low-income mothers using an interactive voice response system. Matern Child Health J. 2012;16:921-8.

34. Maia BR, Pereira AT, Marques M, Bos S, Soares MJ, Valente J, et al. The role of perfectionism in postpartum depression and symptomatology. Arch Womens Ment Health. 2012;15:459-68.

35. Čuržik D, Begić NJ. The utility of BDI-II in assessment of pre- and postpartum depression symptoms and their relation to labor pain. Psychiatr Danub. 2012;24:167-74.

36. Apter G, Devouche E, Gratier M, Valente M, Nestour AL. What lies behind postnatal depression: is it only a mood disorder? J Pers Disord. 2012;26:357-67.

37. Baines T, Wittkowski A, Wieck A. Illness perceptions in mothers with postpartum depression. Midwifery. 2013;29:779-86.

38. Beck CT. The effects of postpartum depression on maternal-infant interaction: a meta-analysis. Nurs Res. 1995;44:298-304.

39. Whiffen VE. Screening for postpartum depression: a methodological note. J Clin Psychol. 1988;44:367-71.

40. Cox JL, Holden JM, Sagovsky R. Detection of postnatal depression. Development of the 10-item Edinburgh Postnatal Depression Scale. Br J Psychiatry. 1987;150:782-6.

41. Boyd RC, Le HN, Somberg R. Review of screening instruments for postpartum depression. Arch Womens Ment Health. 2005;8:14153.

42. Gibson J, McKenzie-McHarg K, Shakespeare J, Price J, Gray R. A systematic review of studies validating the Edinburgh Postnatal Depression Scale in antepartum and postpartum women. Acta Psychiatr Scand. 2009;119:350-64.

43. Harvey ST, Pun PK. Analysis of positive Edinburgh Depression Scale referrals to a consultation liaison psychiatric service in a twoyear period. Int J Ment Health Nurs. 2007;16:161-7.

44. Elisei S, Lucarini E, Murgia N, Ferranti L, Attademo L. Perinatal depression: a study of prevalence and of risk and protective factors. Psychiatr Danub. 2013;25:S258-62.

45. Figueira $\mathrm{P}$, Corrêa H, Malloy-Diniz L, Romano-Silva MA. Edinburgh Postnatal Depression Scale for screening in the public health system. Rev Saude Publica. 2009;43:79-84.

46. Murray L, Carothers AD. The validation of the Edinburgh Postnatal Depression Scale on a community sample. Br J Psychiatry. 1990;157:288-90

47. O'Hara MW, Swain AM. Rates and risk of postpartum depression: a meta-analysis. Int Rev Psychiatry. 1996;8:37-54.

48. Gaynes BN, Gavin N, Meltzer-Brody S, Lohr KN, Swinson T, Gartlehner G, et al. Perinatal depression: prevalence, screening accuracy, and screening outcomes. Evid Rep Technol Assess (Summ). 2005;119:1-8.

49. Lucero NB, Beckstrand RL, Callister LC, Sanchez Birkhead AC. Prevalence of postpartum depression among Hispanic immigrant women. J Am Acad Nurse Pract. 2012;24:726-34.

50. Chaudron LH, Szilagyi PG, Tang W, Anson E, Talbot NL, Wadkins $\mathrm{HI}$, et al. Accuracy of depression screening tools for identifying postpartum depression among urban mothers. Pediatrics. 2010;125:e609-17.

51. American Psychiatric Association. Diagnostic and Statistical Manual of Mental Disorders, Fourth Edition (DSM-IV). Arlington: American Psychiatric Publishing; 1994.

52. American Psychiatric Association. Diagnostic and Statistical Manual of Mental Disorders, Fifth Edition (DSM-5). Arlington: American Psychiatric Publishing; 2013.

53. Cox J. Postnatal mental disorder: towards ICD-11. World Psychiatry. 2004;3:96-7.

54. O'Hara MW, McCabe JE. Postpartum depression: current status and future directions. Annu Rev Clin Psychol. 2013;9:379-407.

55. O'Connor E, Rossom RC, Henninger M, Groom HC, Burda BU. Primary care screening for and treatment of depression in pregnant and postpartum women: evidence report and systematic review for the US preventive services task force. JAMA. 2016;315:388406.

\section{Correspondence:}

Amaury Cantilino

Rua Padre Carapuceiro, 968, sala 108, Boa Viagem

51020-280 - Recife, PE - Brazil

E-mail: cantilino@hotmail.com 